\title{
Colloquy
}

\section{CRITICAL SECURITY AND ANTHROPOLOGY FROM THE MIDDLE EAST}

\author{
GIULIA EL DARDIRY \\ McGill University \\ (iD https:/ / orcid.org/0000-0001-7771-5854 \\ SAMI HERMEZ \\ Northwestern University in Qatar \\ (iD) https:/ / orcid.org/0000-0001-9509-9514
}

Merely invoking the Middle East in the West conjures up notions of terrorism, conflict, crisis, and insecurity. The region's geostrategic significance, coupled with an intensification of political conflict since 9/11, has also associated the Middle East with notions of security in the popular imagination, leading to a proliferation of security studies about the region. Certainly, the Middle East is not unique in any single security issue it faces. The intensity, variety, and scale of insecurities in the region, however, provide both a fertile site from which to think (in)security and a stark reminder of our responsibility to act in a world seeing a rise of insecurity accompanied by a rise of securitization - usually used to justify an accelerated, and often illegal, expansion of state power. We use parentheses around (in)security to highlight, as the authors in this colloquy do, the symbiotic imbrication between the terms, and to center the idea that security often in fact heightens insecurity.

Anthropology has recognized security as a "traveling signifier" that permeates almost all spheres of human activity (Abraham 2009). It has also understood security both in its more traditional sense as a product of governance and state 
power and as "the experiential, affective, and embodied forms that security takes as it is produced in social life" (Glück and Low 2017, 286-87). Anthropologists have, therefore, increasingly begun to interrogate concepts of security and securitization generally (Diphoorn and Grassiani 2015), as well as in relation, for example, to the body (Maguire, Rao, Zurawski 2018), race (Browne 2015), policing (Fassin 2013), (counter)terrorism and border control (Samimian-Darash and Stalcup 2016), and affect (Ochs 2011). The discipline has also responded to the U.S. government's efforts to militarize anthropology to aid its wars abroad, with debates surfacing around the Human Terrain System as one node in the discipline's contribution to the study of security (Forte 2011).

The essays in this colloquy take the Middle East as a case through which to build anthropological knowledge about how (in)security is understood, produced, and deployed by bringing ethnography to bear on the concept. They form part of a longer process of collective thinking that started with a workshop held in the Lebanese capital Beirut in September 2018, where seventeen scholars came together to consider the turmoil in the region from the perspective of people's everyday experiences of living in and through (in)security. This workshop was supported by the Beirut School Network of Critical Security Studies, a working group based at the Arab Council for the Social Sciences. The impetus for this collective project was the realization that though the field of security studies has seen widespread rethinking in past decades - moving away from a narrow Cold War-era focus on the state, superpower rivalry, and the military - much work on securitization, even of the critical variety, remains characterized by a hegemonic understanding of and approach to security that often goes unexamined, and that continues to emphasize traditional Euro-American threats like terrorism (Abboud et al. 2018).

A number of scholars have challenged this persistence of old concepts to clarify the nuances of war and peace in the region. This work has addressed new processes of securitization in Egypt and elsewhere (Grove 2015); the genealogies and implications of two major regional contemporary counterinsurgencies, namely, in Palestine and Iraq (Khalili 2012); the political economy of the 2011 Arab uprisings (Dahi 2011); and how understandings of security among regional state elites conflict with experiences of insecurity among other regional social actors (Hazbun 2015). The Beirut School project builds on this scholarship to advance a critical discourse around securitization and (in)security in the Middle East, informed by deep local knowledge and benefiting from the all-too-often isolated perspectives of different disciplinary traditions. 
This colloquy is held together by the attempt to work with a contrapuntal understanding of security that is subverted from its original meaning and captured from the state. In so doing, it asks: What can the lives of people bearing the brunt of global security technologies tell us? If invoking security often justifies injustice (Stewart and Choi n.d.), how might a critical study of security offer views of life worlds that do not privilege security as the ordering principle of social life (Bajc and de Lint 2011)? How might ethnography elucidate the moral and political economy of security? The reader will find running through the pieces a notion of crisis put in tension with the longue durée and normalcy of political conflict. We know that notions of crisis often mask preexisting or ongoing conflict, deflect political critique, or justify state policies such as emergency laws. What the authors show us, however, is what the experience of security and its attendant technologies, practices, and discourses look like from the perspective of those living-in-crisis, borrowing from Lamia Moghnieh's (2017) living-in-violence, when crisis becomes chronic - a way of life — and yet remains imagined, desired, and often articulated as an exception.

Legitimate skepticism exists around the project of a critical discourse of security, owing to a reluctance to operate on the state's terms and to reinscribe security as a hegemonic framework. Despite this, we resist sidestepping the notion of security in favor of less compromised terminologies, such as precarity, for a number of reasons. First, security is interesting precisely because a deep tension exists between people's desire to feel secure and security's potentially deadly hold on their lives. Second, the pervasiveness and intensity of security discourses in academia and the world at large make a direct and explicit engagement with the concept necessary, even - and perhaps especially — if one's aim is to ultimately move beyond it. Third, the term has local currency as well as material consequences that the authors' interlocutors must confront. Many of the individuals portrayed in the essays know how they and their narratives feature in security discourses that justify the brutalization of their lives. Their lives show, however, the myriad meanings and experiences of security that exist across the Middle East. Together, the articles demonstrate the existence of significantly more complex, more resistant, more dangerous variations of security than commonly acknowledged.

Ross Porter's (2020) ethnography of the 2011 revolution in Yemen, and specifically, of a revolutionary encampment in the city of Sana'a, draws attention to the ways in which security becomes actively mobilized against the state from below. Porter inverts the concept of securitization as a state-led process to consider how world-building projects such as revolutions both diffuse and reappro- 
priate processes of securitization for their own ends. In describing how a trust network between a haphazard set of actors forms in order to smuggle medicine into ISIS-controlled areas of Iraq, Kali Rubaii (2020) examines the relationship between trust and (in)security, and calls on us to question how trust materializes and operates in conflict zones. Emrah Yıldız (2020) uses a conversation with an Iranian friend to explore the political economy of Iranian sanctions. He reveals how various (in)securities faced daily by Iranians come to nest within one another. Diana Allan (2020) provides an ethnographic portrait of a Palestinian refugee friend who traveled from Lebanon to Belgium through illegal means so as to think through what it might mean to live one's entire life insecurely. This attention to the lived experience of a single individual provides an entry point for a broader critique of the normative privileging of states and borders in theorizations of security. Finally, Darryl Li (2020) takes his encounter with an Algerian migrant-cum-spy in a Bosnian detention center to both open up debate about how the state deals with illicit people and to show how security apparatuses - in this case, intelligence gathering_-directly intersect with people's lived experiences of (in)security.

Together, the authors explore the complex relationship inherent within (in)security and clarify how security is handled when political violence constitutes the norm. In the work of Rubaii and Ylldı, smuggling routes become sources of social security that form alternative modes of trust. Reading Porter alongside Rubaii, we discover the value of a critique of trust and its entanglement with security. In Allan and Li, we see how people navigate the precarious terrain of (il)legal statuses — with and without state sanction - as they seek to find a halcyon zone in which to live. These authors show us not just how people and objects (like currencies) flow across borders in an attempt to find safety but also, importantly, how security regimes themselves flow across borders, extend their tentacles, and find their way into the intimate recesses of our lives. Sanctions imposed by a U.S. administration, for example, govern Iranian lives, and a Saudi-led initiative attempts to short-circuit a revolutionary process in Yemen. We must thus view security issues as "nested," in Yıldız's terms, and as traveling along a metaphorical archipelago (Amar 2013).

Beyond a discourse and a practice, security also constitutes an affect that travels and gives way to further affects. Conceptualized as such, (in)security not only produces negative and positive affects, such as fear or comfort, but is itself affecting - it is an emotion, as when people speak of a sense of security. The essays show how people's sense of (in)security is imagined, and how it permeates borders and coexists with other senses, as in Porter's discussion of how Yemen's Change 
Square becomes a safe space for revolutionaries despite feelings of mistrust and anxiety. Smugglers, spies, and refugees travel with their sense of (in)security in their proverbial luggage, producing and produced by feelings such as fear, anxiety, and mistrust. Importantly, we see in these essays how people can outwit the state by cultivating immunity to certain security affects.

In tackling (in)security, we further suggest storytelling, and specifically a focus on life-writing, as an ethnographic method that can draw out the tensions embedded in (in)security. Li and Allan take this approach and demonstrate the sense of security that resides in the ability to tell one's story. They allow the practice of storytelling embedded in life-writing to draw out security affects. Through stories told, ethnographers manage to reveal the security affects facing those whose life stories are being told and, in turn, make readers viscerally feel insecure lives. Life-writing thus manages to resist or circumvent hegemonic ways of explaining states of insecurity and security states.

We can extrapolate from the mélange of scenes in this collection the diversity of stories extant about (in)security: of spies, revolutionary youth, doctors, refugees, and commodity traders. Security seems to interact in varied and mismatched ways with daily life in a region overdetermined by security discourse. But what fundamentally connects these stories is that all grapple with people living-in-crisis, and all take place under the shadow of a global security regimenot just discourses, but a true military-industrial complex - that wreaks havoc on their lives. We hope this colloquy clarifies the existence of multiple strategies for people to move out of this shadow to secure their lives. And we hope that what emerges is evidence of how people's practices, even if at times illegal or precarious, prove more stabilizing than state security interventions.

\begin{abstract}
This colloquy takes the Middle East region as a starting point from which to explore a contrapuntal concept of security that is subverted from its original meaning and captured from the state. The essays follow the lives of revolutionary youth, doctors, commodity traders, refugees, and spies to examine their experiences of (in)security. In doing so, the essays deploy storytelling and other ethnographic forms to think of the political economy, emotions, flows, and ethics of security from the perspective of those living-in-crisis. [critical security, crisis, ethnography, everyday life, Middle East]
\end{abstract}




\section{NOTES}

Acknowledgments We thank the Wenner-Gren Foundation, the Arab Council for the Social Sciences (ACSS), and Northwestern University in Qatar for the generous support that allowed us to gather a wonderful group of scholars and hold our workshop, "Insecurity and Everyday Life: Perspectives from the Middle East," in Beirut, Lebanon. Thank you to all the participants of the September 2018 workshop, to Omar Dahi and Lori Allen, who read a version of the introduction, and to the Cultural Anthropology editorial collective and the journal's anonymous reviewers for their valuable feedback. Perhaps most of all, this collection would not be possible without the various interlocutors who are identified in pseudonym only-precisely because of the politics of (in)security - and who yet constitute its primary theorists and protagonists.

\section{REFERENCES}

Abboud, Samer, Omar S. Dahi, Waleed Hazbun, Nicole Sunday Grove, Coralie Pison Hindawi, Jamil Mouawad, and Sami Hermez

2018 “Towards a Beirut School of Critical Security Studies." Critical Studies on Security 6, no. 3: 273-95. https://doi.org/10.1080/21624887.2018.1522174.

Abraham, Itty

2009 "Segurança/Security in Brazil and the United States." In Words in Motion: Toward a Global Lexicon, edited by Carol Gluck and Anna Lowenhaupt Tsing, 21-39.

Allan, Diana

Durham, N.C.: Duke University Press.

2020 "The Long Turning: A Palestinian Refugee in Belgium." Cultural Anthropology 35, no. 2: 225-30. https://doi.org/10.14506/ca35.2.05.

Amar, Paul

2013 The Security Archipelago: Human-Security States, Sexuality Politics, and the End of Neoliberalism. Durham, N.C.: Duke University Press.

Bajc, Vida, and Willem de Lint, eds.

2011 Security and Everyday Life. New York: Routledge.

Browne, Simone

2015 Dark Matters: On the Surveillance of Blackness. Durham, N.C.: Duke University Press.

Dahi, Omar S.

2011 "Understanding the Political Economy of the Arab Revolts." Middle East Report 259: 2-6.

Diphoorn, Tessa, and Erella Grassiani

2015 "Introduction: Security." Etnofoor 27, no. 2: 7-13. https://www.jstor.org/ stable/43656016.

Fassin, Didier

2013 Enforcing Order: An Ethnography of Urban Policing. Cambridge, UK: Polity Press.

Forte, Maximilian C.

2011 "The Human Terrain System and Anthropology: A Review of Ongoing Public Debates." American Anthropologist 113, no. 1: 149-53. https://doi.org/10.1111/ j.1548-1433.2010.01315.x.

Glück, Zoltán, and Setha Low

2017 "A Sociospatial Framework for the Anthropology of Security." Anthropological Theory 17, no. 3: 281-96. https://doi.org/10.1177\%2F1463499617729229.

Grove, Nicole Sunday

2015 "The Cartographic Ambiguities of HarassMap: Crowdmapping Security and Sexual Violence in Egypt." Security Dialogue 46, no. 4: 345-64. https://doi. Hazbun, Waleed org/10.1177\%2F0967010615583039.

2015 "A History of Insecurity: From the Arab Uprisings to ISIS." Middle East Policy 22, no. 3: 55-65. https://doi.org/10.1111/mepo.12143. 
Khalili, Laleh

2012 Time in the Shadows: Confinement in Counterinsurgencies. Stanford, Calif.: Stanford University Press.

Li, Darryl

2020 “The Spy Who Came In from the South.” Cultural Anthropology 35, no. 2: 231-36. https://doi.org/10.14506/ca35.2.06.

Maguire, Mark, Ursula Rao, and Nils Zurawski, eds.

2018 Bodies as Evidence: Security, Knowledge, and Power. Durham, N.C.: Duke University Press.

Moghnieh, Lamia

2017 “The violence we live in': Reading and Experiencing Violence in the Field." Contemporary Levant 2, no. 1: 24-36. https://doi.org/10.1080/20581831.2017.1318 804.

Ochs, Juliana

2011 Security and Suspicion: An Ethnography of Everyday Life in Israel. Philadelphia: University of Pennsylvania Press.

Porter, Ross

2020 "Security against the State in Revolutionary Yemen." Cultural Anthropology 35, no. 2: 204-10. https://doi.org/10.14506/ca35.2.02.

Rubaii, Kali

2020 "Trust without Confidence: Moving Medicine with Dirty Hands." Cultural Anthropology 35, no. 2: 211-17. https://doi.org/10.14506/ca35.2.03.

Samimian-Darash, Limor, and Meg Stalcup

2016 "Anthropology of Security and Security in Anthropology: Cases of Counterterrorism in the United States." Anthropological Theory 17, no. 1: 60-87. https://doi.org/10.1177\%2F1463499616678096.

Stewart, Michelle, and Vivian Choi

n.d. "Security: A Conversation with the Authors." Curated Collections, Cultural Anthropology. Accessed June 10, 2019. https://journal.culanth.org/index.php/ca/ Ylldız, Emrah security-conversation-with-the-authors.

2020 "Nested In(securities): Commodity and Currency Circuits in an Iran under Sanctions." Cultural Anthropology 35, no. 2: 218-24. https://doi.org/10.14506/ ca35.2.04. 